Kosjenka Laszlo Klemar

Tehnički muzej Nikola Tesla

Zagreb

kosjenka.laszlo.klemar@tmnt.hr

Željka Miklošević

Filozofski fakultet Sveučilišta u Zagrebu

Zagreb

zmiklosevic@ffzg.hr
DOI: $10.32458 /$ ei.25.4

UDK 069.12(497.5)

Stručni rad

Primljeno: 22. svibnja 2020.

Prihvaćeno: 25. svibnja 2020.

\title{
Edukativna muzejska akcija - obilježja i mogućnosti razvoja
}

Obilježavajući Međunarodni dan muzeja, hrvatski muzeji provode Edukativnu muzejsku akciju (EMA) provođenjem edukacijskih aktivnosti - najčešće radionica, vodstava i edukativnih izložbi - na specifičnu temu koju zadaje muzej-voditelj. Etnografski muzeji u Hrvatskoj su u akciji sudjelovali od samih početaka, a Etnografski muzej u Zagrebu bio je i voditelj edukativne muzejske akcije 2000. i 2010. godine. U članku je predstavljeno istraživanje o obilježjima EMA-e kao edukativne muzejske akcije koje je bilo provedeno analizom tiskanih knjižica kao programskih publikacija Akcije te odgovora muzejskih stručnjaka koji su sudjelovali u organizaciji i provođenju Akcije dobivenih anketom. Istraživanjem se pokazuje nesklad između naziva i obilježja ove organizirane aktivnosti na temelju čega se propituje stanje i potencijali razvoja Akcije, ali i muzejske edukativne djelatnosti. Kustosi etnografskih zbirki i muzejski pedagozi u hrvatskim etnografskim muzejima koji su sudjelovali u istraživanju doprinijeli su određivanju problematike vezane za muzejske edukativne programe kao i određivanju njezinih razvojnih potencijala.

Ključne riječi: edukativne muzejske akcije, muzejska pedagogija, Hrvatska

\section{UVOD}

Veoma se često ističe važnost muzeja kao mjesta u kojima se mogu dobiti zanimljive i raznolike informacije i mjesta u kojima se uči. Edukacija je naglašena u još uvijek aktualnoj definiciji muzeja koju je Međunarodni savjet za muzeje donio na 22. Generalnoj skupštini u Beču 2007. godine (ICOM 2007.), a jedna je od osnovnih muzejskih 
djelatnosti i prema važećem Zakonu o muzejima (NN 61/18, 98/19). Premda je danas mali broj onih koji u muzejske aktivnosti ne bi uključili i one edukativne, borba za priznavanje važnosti muzejske edukacije vodila se niz godina počevši od 1960-ih na dalje, primarno u međunarodnim krugovima, ali ponešto i kod nas (Bauer 1975., Brezinščak i Jelavić 1996., Jelavić 2011., Majanović 1994., Škarić 2002., 2007., 2010.). Međutim, unatoč velikom broju objavljenih radova o muzejskim edukativnim aktivnostima u nas, primarno u Zbornicima skupova muzejskih pedagoga (Brezinščak 2019.), veoma malo se pisalo o tome što je muzejska edukacija, koji su njezini ciljevi i svrha. Još se manje pisalo o terminologiji. Stoga su, u nedostatku općeprihvaćenih definicija, isti termini nerijetko korišteni za označavanje međusobno različitih sadržaja. Među njima se nalazi i termin edukativna akcija, koji se susreće i u nazivu najdugovječnije muzejsko-pedagoške manifestacije hrvatskih muzeja - edukativne muzejske akcije (EMA).

Cilj ovoga rada je ispitati što ova muzejska manifestacija podrazumijeva, posjeduje li karakteristike edukativne akcije, koji su stavovi i mišljenja struke (organizatora i provoditelja) te temeljem rezultata prodiskutirati stanje i potencijale njezina razvoja, ali i stanje muzejsko-pedagoške struke u cjelini. U svrhu dobivanja širega i dubljega uvida u obilježja akcije provedeno je kvantitativno i kvalitativno istraživanje usmjereno na muzejske pedagoge/-inje i ostale muzealce/-kinje uključene u njezinu organizaciju.

Rad započinje pokušajem definiranja pojma edukativna akcija, nakon čega slijedi kratka povijest Edukativne muzejske akcije (EMA), s posebnim osvrtom na uključenost u programe etnografskih muzeja te potom metodologija istraživanja, rezultati istraživanja, interpretacija rezultata i zaključak.

\section{PREMA ODREĐENJU POJMA}

Riječ akcija dolazi od latinskog lat. actio $\simeq$ agere: djelovati. Akcija u hrvatskom jeziku ima nekoliko značenja, od kojih je prvo "djelovanje, radnja, pothvat", a treće "organizirana društvena ili politička djelatnost". U engleskom jeziku se riječ action definira kao proces ili djelatnost, posebno kada je riječ o nekom problemu (Cambridge Dictionary 2018.). Prema navedenim značenjima, edukativnu akciju možemo tumačiti kao organizirano djelovanje, radnju, pothvat ili proces koji edukacijom nastoji ostvariti određeni cilj ili riješiti određeni problem. Edukativna akcija je sintagma kojom se označava djelovanje drugačije od uobičajene edukativne prakse u školama ili muzejima a istovremeno znači neko specifično edukacijsko djelovanje ili pothvat.

Edukativne akcije se u javnom diskursu najčešće susreću u kontekstu borbe protiv karcinoma, ekologije i sličnih tema važnih za pojedine skupine ljudi i društvo u cjelini. U muzeološkoj literaturi pojam edukativne akcije vrlo je rijedak. Koristi se ponajprije u latinoameričkim državama (španj. acción educativa), ali nije jasno definiran i vidljivo je da ne postoji konsenzus među muzejskim stručnjacima i teoretičarima što točno podrazumijeva. Riječ "akcija” u kontekstu muzeja spominje se i u sintagmi kulturna akcija od 1960-ih do danas, prvo u Francuskoj (action culturelle), a onda se širi i na druge zemlje. Širenje termina može se povezati i s djelovanjem ICOM-ova komiteta za edukaciju u muzejima čije je sjedište u Francuskoj (Komitet za edukaciju i kulturnu 
akciju - CECA), a u kojem sudjeluju muzealci iz cijeloga svijeta, uključujući Hrvatsku. U Hrvatskoj je sintagma prisutna u nazivu HMD-ove sekcije koja koordinira EMA-u (Sekcija za muzejsku pedagogiju i kulturnu akciju). No, niti kulturna akcija nije jednoznačno definirana o čemu zorno svjedoči publikacija ICOM Education br. 28 posvećena upravo tom problemu (usp. Wintzerith 2018a). Objavljeni tekstovi pokazuju da se i edukativna akcija i kulturna akcija i muzejska edukacija općenito u muzejima shvaćaju na različit način, te su podložni različitim tumačenjima s obzirom na specifične okolnosti u pojedinim društveno-kulturnim kontekstima. Štoviše u uvodu navedene publikacije postavlja se pitanje postoji li uopće razlika između edukativne i kulturne akcije (usp. Wintzerith 2018b). Anne-Marie Émond i João Pedro Pais Mendonça, koji se u povijesnom pregledu muzejske edukacije i kulturne akcije u engleskom dijelu Kanade osvrću i na suvremenu muzejsku praksu, jasno razlikuju muzejsku edukaciju i kulturnu akciju. Prema njima, od kraja 20. st. pa sve do danas, muzejska edukacija podrazumijeva aktivnosti kao što su "vođene ture, radionice, programi za škole izvan muzeja, korištenje svih tehnoloških alata", dok muzejska kulturna akcija podrazumijeva "razvoj specifičnih programa, oblikovanih za specifične potrebe i u suradnji s ciljanom publikom različitih zajednica" (Émond i Pais Mendonç 2018: 102). U kontekstu Latinske Amerike, pak, muzejska edukativna akcija ima naglasak na učenju o baštini i podrazumijeva niz aktivnosti koje karakteriziraju razrađena strategija provođenja, definirane ciljane skupine korisnika i jasno definiran pedagoški cilj (usp. Aidar i Conrado Martins 2018.).

Za razliku od navedenih prilično nejasnih određenja edukativne akcije u muzeološkoj literaturi i očitih preklapanja između poimanja značenja muzejske edukacije, edukativne akcije i kulturne akcije, britanski sociolog Martyn Hammersley donosi mnogo jasnije tumačenje pojma te pritom jasno razlikuje akciju s edukativnom intencijom od akcije s intencijom informiranja. Prema njemu, edukativna akcija: 1. mora imati definiranu specifičnu ciljanu publiku, 2. mora biti osmišljena s namjerom da se postigne neka promjena u shvaćanju korisnika/ciljane publike na koje je usmjerena, u stavovima ili načinu njihova ponašanja kako bi mogli zadovoljiti svoje potrebe, 3 . mora biti jasno usmjerena na ostvarivanje edukativnih ciljeva - važno je događa li se zaista edukacija koja se namjeravala provesti, 4. komunikacija informacija ne može biti primarna aktivnost, već samo jedna u nizu aktivnosti koje se provode u procesu edukacije (Hammersley 2003: 16). Ove odlike Hammersley suprotstavlja informativnoj akciji, ili činu informiranja, koja podrazumijeva: 1 . pružanje znanja za koje se vjeruje da je od interesa za ljude, 2. brigu o valjanosti i relevantnosti pruženoga znanja, 3. komunikaciju informacija kao jedini čin, te 4. prilično nedefiniranu publiku. Slijedom obilježja edukativne akcije, koja se razlikuje od informativne, a imajući na umu i muzeološka viđenja, dolazimo, ako ne do jasne definicije, onda barem do prijedloga obilježja organiziranoga događaja koji se može nazvati muzejskom edukativnom akcijom. Muzejska edukativna akcija bila bi, dakle, organizirano djelovanje, radnja, pothvat ili proces u svrhu postizanja nekoga specifičnog (edukativnog) cilja, koja se provodi u muzeju/-ima ili u organizaciji muzeja. Ona se nužno razlikuje od redovitih edukativnih aktivnosti. Aktivnosti muzeja/muzejskih djelatnika pod okriljem akcije moraju imati jasno definiranu ciljanu skupinu ili više skupina, definirane svrhe i vrste te definirane edukativne ciljeve i biti usmjerene na njihovo postizanje. 


\section{OD IGRE DO AKCIJE - KRATKI PREGLED RAZVOJA EDUKATIVNE MUZEJSKE AKCIJE}

Edukativna muzejska akcija provodi se u Hrvatskoj već više od dva desetljeća i njezin se osnovni koncept od začetka nije bitno mijenjao. Obilježavajući Međunarodni dan muzeja, EMA podrazumijeva održavanje pedagoških programa na specifičnu temu koju zadaje muzej-voditelj. Kupnjom tiskane knjižice, s kratkim informacijama o temi i programima Akcije, korisnici ostvaruju besplatan ulaz u sve uključene muzeje i besplatno sudjelovanje u prigodnim programima. Hrvatski etnografski muzeji u akciji sudjeluju od samoga početka i u sklopu nje su proveli na desetke edukativnih programa.

Prvo organizirano muzejsko edukativno djelovanje, nepretenciozno nazvano muzejskom nagradnom igrom, održano je 1996. godine pod nazivom "Što je u muzeju oduševilo Baltazara?” Inicirao ju je kolegij kustosa pedagoga zagrebačkih muzeja, organizirao ju je Muzejski dokumentacijski centar, a vodio Želimir Laszlo u suradnji s Tončikom Cukrov (Laszlo 1997., Leiner i Brezinščak 2016.). Poticaj za njezino pokretanje bila je specifična situacija uzrokovana Domovinskim ratom. Naime, od 1991. pa sve do 1996. godine zbog opasnosti od ratnih razaranja, muzejski fundusi su bili pohranjeni u depoima i nedostupni javnosti. Nekoliko generacija djece završilo je niže i krenulo $\mathrm{u}$ više razrede osnovne škole, a da nije imalo priliku posjetiti ni jedan muzej pa onda niti otkriti značaj i važnost muzejskih zbirki, a kamoli razviti naviku posjeta muzejima (Laszlo 1997.). Ciljevi akcije bili su jasno postavljeni: 1. da djeca uoče mnogobrojnost i različitost muzeja; 2 . da djeca spoznaju množinu i vrstu izložaka; 3. da svako dijete pomnije razgleda barem jedan predmet i nauči se koristiti muzejskom legendom. Kako bi privukli djecu i potaknuli ih na sudjelovanje, autori koncepcije su za glavnoga lika (svojevrsnu maskotu) izabrali profesora Baltazara, poznatoga lika kultne hrvatske istoimene animirane serije Zagrebačke škole crtanog filma. Igru je pratila knjižica u kojoj su djeca-sudionici sakupljali štambilje posjećenih muzeja i upisivali podatke o muzejskim predmetima koji su bili dio igre i koje su u muzejima otkrivali. U igru se uključilo 14 muzeja iz Zagreba i Zagrebačke županije, među kojima i Etnografski muzej u Zagrebu. Trajala je mjesec dana, a završna svečanost je održana na Međunarodni dan muzeja, 18. svibnja 1996. Igra nije bila tematski definirana, već se sadržajem djelomično vezala uz temu Međunarodnoga dana muzeja koja je te godine bila kolekcionarstvo (Skupljamo danas za sutra), a na način da su djeca skupljala muzejske žigove. Bila je usmjerena na individualne posjetitelje, a organizirane (školske) posjete su namjerno izbjegnute kako djeca ne bi bila "prisiljena" sudjelovati. Rezultati su bili vrlo dobri - prodano je više od 3000 knjižica, više od 800 osnovnoškolaca ispunilo je sve zadatke koji su se nalazili u knjižici, a na završnoj svečanosti koja se održala u Tehničkom muzeju u Zagrebu (danas Tehnički muzej Nikola Tesla) sudjelovalo je više od 2000 djece (Laszlo 1997.).

Premda je inicijalno zamišljena kao jednokratno djelovanje koje je očito imalo obilježje akcije, sa specifičnim ciljem i potaknuta situacijom post-ratnoga "oporavka", zbog velikoga uspjeha te interesa muzeja iz drugih gradova za uključivanjem, održavanje muzejske nagradne igre nastavljeno je narednih godina u vidu jednomjesečnoga događanja te se s vremenom pretvorilo u svojevrsnu tradiciju. Već 1997. godine organizaciju akcije preuzeli su muzeji, a prvi među njima bio je Arheološki muzej u Zagrebu. Nakon 
osnivanja Sekcije muzejskih pedagoga pri Hrvatskom muzejskom društvu 1999. godine, ona od Muzejskoga dokumentacijskog centra preuzima funkciju nadležnoga tijela (voditelja) koje potvrđuje/izabire muzeje-organizatore. Od 1997. do 2020. godine na mjestu organizatora izmijenilo se 19 muzeja, među kojima i Etnografski muzej u Zagrebu koji je funkciju obnašao čak dva puta - 2000. (“2000”) i 2010. ("Kotač"). Od 1997. godine nadalje svaka muzejska akcija ima središnju temu koju osmišljava muzej-organizator.

Sukladno razvoju muzejske pedagogije u Hrvatskoj (koja je nakon stagnacije tijekom prve polovine 1990-ih u vrijeme pokretanja nagradne igre "Što je u muzeju oduševilo Baltazara?" započinjala svoj novi uzlet) razvijao se i sadržaj akcije, a s godinama se povećavao i broj uključenih gradova i muzeja (Leiner i Brezinščak 2016.).

Uvid u razvoj edukativne muzejske akcije najbolje pružaju programske knjižice koje su tiskane uz svaku akciju. Uz informacije o muzeju-organizatoru i središnjoj temi u njima se nalaze popisi uključenih muzeja i opisi programa. Zahvaljujući tomu može se pratiti postupno širenje akcije iz Zagreba i Zagrebačke županije prvo na susjednu Krapinsko-zagorsku županiju (1999.) te potom tijekom 2000-tih, i na ostatak Hrvatske. U 11. muzejsku edukativnu igru s temom "Zvuk...Ton...Glas" održanu 2006. godine (organizator: Hrvatski povijesni muzej) bile su uključene sve regije Hrvatske, ukupno 42 ustanove (uz muzeje akciji se već ranih 2000-tih priključuju srodne ustanove, primarno galerije i arhivi) iz 20 gradova. Osim zagrebačkoga Etnografskog muzeja, u akciju se uključuju i ostali etnografski muzeji diljem Hrvatske (2006. su uz zagrebački Etnografski muzej sudjelovali i Etnografski muzej Istre te Etnografski muzej Split).

Osim teritorijalnoga širenja 2006. godine širi se i ciljana publika pa se uz djecu osnovnoškolske dobi uključuju srednjoškolci i "svi zainteresirani” (Cukrov 2006., Smetko 2006.). Širenje ciljane publike na mlade može se dovesti u vezu s ICOM-ovom temom Međunarodnoga dana muzeja te godine - "Muzeji i mladi posjetitelji". Etnografski muzeji akciji su se također odazvali s programima radioničkoga karaktera vezanim uz tradicijske instrumente (Zagreb - tamburica, Istra - sopele, Split - gusle, mandoline, diple), pri čemu je samo program Etnografskoga muzeja u Zagrebu uz radionicu uključivao i posjet izložbi te projekciju filma, a temi je pristupio problemski uz poticanje polemike i rasprave (naziv programa: "Tamburica - simbol hrvatskoga nacionalnog identiteta?" autorica izložbe: Zvjezdana Antoš, autorica edukativnog programa: Željka Jelavić) te je u tom smislu bio prikladniji za sudjelovanje srednjoškolaca. Zanimljiva je i promjena naziva akcije iz "muzejska edukativna nagradna igra" u "muzejska edukativna akcija i nagradna igra" 2008. godine, da bi se 2010. i 2011. ponovno vratio stari naziv "muzejska edukativna igra". Od 2012. na dalje koristi se isključivo naziv "muzejska edukativna akcija" i to od 2016. uz skraćenicu EMA. Promjene naziva nisu bile praćene promjenom koncepcije igre/akcije. Ona je sve to vrijeme ostala ista - tijekom mjesec dana trajanja igre/akcije sudionici obilaze muzeje s knjižicom u kojoj prikupljaju žigove, a sve završava velikom svečanošću na Međunarodni dan muzeja (18. svibnja) na kojoj se dodjeljuju nagrade (na zadnjoj stranici knjižice se skupljaju žigovi te se ta stranica šalje na adresu muzeja-organizatora, a svi koji pošalju taj list sudjeluju u izvlačenju za nagrade). Naziv redovito sadrži dodatak "povodom Međunarodnog dana muzeja", kojim se naglašava povezanost s Međunarodnim danom muzeja u organizaciji Među- 
narodnoga savjeta za muzeje (ICOM). Ta se povezanost prvenstveno odnosi na termin održavanja, odnosno veliko "finale" na Međunarodni dan muzeja, dok su teme rijetko povezane s ICOM-ovom temom.

\section{METOdOLOGIJA ISTRAŽIVANJA}

Kako bismo pobliže odredili obilježja Akcije u hrvatskim muzejima, vodili smo se određenjem edukativne akcije temeljenom na prije navedenim premisama Martyna Hammersleya (2003.) te svojstvima muzejske edukativne akcije latinoameričkih muzeja (Aidar i Conrado Martins 2018.), odnosno kulturne akcije kanadskih muzeja s engleskoga govornog područja (Émond i Mendonça 2018.). Istraživanje je imalo za cilj propitati u kojoj mjeri hrvatska muzejska akcija svojim obilježjima zadovoljava kategorije: 1 . definirana specifična ciljana publika; 2. definirana vrsta i svrha aktivnosti; 3. definirani edukativni ciljevi i usmjerenost na njihovo postizanje.

Podaci su prikupljani sadržajnom analizom knjižica kao glavnih publikacija svake od provedenih EMA-e te putem internetske ankete s otvorenim i zatvorenim pitanjima koji se tiču aktivnosti sudionika tijekom Akcije. Ciljana skupina ispitanika su bili muzejski pedagozi i kustosi koji najčešće organiziraju ili provode Edukativnu muzejsku akciju, što su pokazala i prijašnja istraživanja provedena u hrvatskim muzejima (Škarić 2010.).

Adrese su preuzete iz baze podataka Muzejskoga dokumentacijskog centra (Hrvatski muzeji i zbirke online) te iz programskih knjižica Akcije. Kako je bilo nemoguće znati tko je od kustosa sudjelovao u Akciji, izbor onih kojima je poslana anketa je bio uvelike nasumičan, no u tekstu elektroničke pošte nalazila se zamolba za prosljeđivanjem ankete onima kojima možda nismo poslali, a sudjelovali su u nekoj od akcija. Anonimna anketa poslana je 30. rujna 2018. godine na 209 adresa elektroničke pošte djelatnika u osnovnim i višim zvanjima kustosa (146) i muzejskoga pedagoga (63), a podaci su analizirani zaključno s anketnim obrascem koji je poslan 31. listopada 2018. godine. Dobiveni podaci obrađeni su metodom deskriptivne statistike (zatvorena pitanja brojčano obradiva) te kvalitativnom i kvantitativnom tematskom analizom sadržaja (otvorena pitanja koja su rezultirala tekstom).

Anketu je otvorilo i započelo s ispunjavanjem 141 muzealaca, a 101 je nastavilo anketu ispunjavati. Na pitanje "Jeste li osobno sudjelovali u organizaciji i/ili realizaciji programa?" odgovorilo je 93 sudionika, a na sva pitanja do kraja ankete je od toga broja odgovorilo njih 70, što je 75,2 \%. Sveukupno je bilo postavljeno 24 pitanja, neka od kojih su nudila dodatan prostor za komentare po želji ispitanika. Prvi dio pitanja odnosio se na radna mjesta i vrsta muzeja u kojem ispitanici rade te sudjelovanje (muzeja i osobno) u EMA-i. Druga skupina pitanja bila je vezana za vrste posjetitelja i programe tijekom Akcije te njezin doprinos korisnicima. Treća skupina pitanja mjerila je stupanj slaganja s izjavama o organizaciji Akcije, programsku knjižicu, teme Akcije, promjene do kojih dovodi te oblik provedbe u budućnosti. S obzirom na temu ovoga rada, prikaz rezultata istraživanja anketom iznijet će se samo vezano za drugu i djelomice treću skupinu pitanja budući da su relevantna za istraživačko pitanje. 


\section{REZULTATI ANALIZE PROGRAMSKIH KNJIŽICA}

Analizu knjižica donosimo prema zadanim kategorijama.

\section{Definirana specifična ciljana publika}

Prva muzejska edukativna akcija/nagradna igra "Što je u muzeju oduševilo Baltazara?" (1996.) imala je jasno definiranu ciljanu skupinu - djeca osnovnoškolskoga uzrasta. Također, bila je otvoreno usmjerena na individualne posjetitelje, a organizirani (školski) posjeti su namjerno izbjegnuti. Djeca osnovnoškolskoga uzrasta predstavljala su ciljanu skupinu i u godinama koje su uslijedile. Tek 2006. u ciljanu skupinu se uz djecu osnovnoškolskoga uzrasta uključuju i srednjoškolci te "svi zainteresirani", što se navodi u tekstu o provedenoj akciji (Cukrov 2006., Smetko 2006.) premda se u samim knjižicama uz pojedinačne programe (opise aktivnosti) uključenih muzeja uglavnom ne navodi kojoj je od navedenih ciljanih skupina program namijenjen. Ta se praksa nastavila u narednim godinama te se ciljana skupina u opisu programa pojedinoga muzeja navodi tek iznimno. Programska je knjižica dizajnom (naročito od 2016. kada se kao središnji lik/maskota uvodi djevojčica Ema) prilagođena djeci nižega osnovnoškolskog uzrasta, no u uvodnim tekstovima (i nakon 2016.) povremeno se kao ciljana publika uz djecu ipak navode i mladi ili čak "svi uzrasti". Promjenu u odnosu na inicijalnu zamisao čini i sve veća usmjerenost ka grupnim, školskim posjetima (najvjerojatnije pod pritiskom ostvarivanja većega broja korisnika, (op.a.)), koje se u prvoj akciji 1996. svjesno nastojali izbjeći.

\section{Vrste i svrha aktivnosti}

Vrste aktivnosti provođenih u sklopu muzejske edukativne akcije iščitavaju se iz opisa aktivnosti uključenih muzeja. Prva akcija usmjerena na poticanje individualnoga istraživanja muzeja razumljivo, nije uključivala organizirane aktivnosti namijenjene grupi korisnika, izuzev u sklopu svečanosti dodjele nagrada. Tijekom narednih godina, s pomicanjem fokusa na grupne posjete, broj aktivnosti raste i uključuje radionice, tematska vodstva, predavanja i edukativne izložbe, odnosno više-manje sve vrste aktivnosti koje se vežu uz muzejsko-edukativnu praksu. Ipak, osobito od 2006. godine na dalje, uočljiva je dominacija kreativnih radionica, koje su u to vrijeme općenito prevladale kao dominantna vrsta muzejsko-pedagoških programa u hrvatskim muzejima. U tom smislu, na programskoj razini, ne može se utvrditi odmak od uobičajene muzejskopedagoške prakse. U opisima programa pojedinih muzeja u programskim knjižicama ne navodi se svrha aktivnosti.

\section{Definirani edukativni ciljevi i usmjerenost na njihovo provođenje}

U prvoj edukativnoj akciji održanoj 1996. edukativni ciljevi su bili jasno definirani: 1 . da djeca uoče mnogobrojnost i različitost muzeja; 2. da djeca spoznaju množinu i vrstu izložaka; 3 . da svako dijete pomnije razgleda barem jedan predmet i nauči se koristiti 
muzejskom legendom. U svrhu njihova postizanja tiskana je radna bilježnica koja je uključivala zadatke koje su djeca trebala izvršiti. U narednim godinama ciljevi nisu jasno komunicirani, a iz uvodnih tekstova u programskim knjižicama se iščitava njihova usmjerenost na povećanje broja posjetitelja, promociju muzeja, očuvanje baštine i sl.

\section{REZULTATI ANKETE}

Sveukupno su bila postavljena 24 pitanja, neka od kojih su nudila dodatan prostor za komentare po želji ispitanika. Prvi dio pitanja odnosio se na radna mjesta i vrste muzeja u kojem ispitanici rade te sudjelovanje (muzeja i osobno) u EMA-i. Druga skupina pitanja bila je vezana za vrste posjetitelja i programe tijekom Akcije te njezin doprinos korisnicima. Treća skupina pitanja mjerila je stupanj slaganja s izjavama o organizaciji Akcije, programsku knjižicu, temama Akcije, promjene do kojih dovodi te oblik provedbe u budućnosti. Uz osnovne podatke o sudionicima i dužini njihova sudjelovanja u akciji, ovdje iznosimo odgovore na pitanja koja su relevantna za postavljeno istraživačko

Slika 1. Za koje skupine posjetitelja i koliko često se organiziraju/provode aktivnosti u sklopu Akcije namijenjene organiziranim grupama?

\begin{tabular}{|c|c|c|c|c|c|c|}
\hline & Nikada & $\begin{array}{l}\text { Izuzetno } \\
\text { rijetko }\end{array}$ & Rijetko & Povremeno & Često & $\begin{array}{l}\text { Izuzetno } \\
\text { često }\end{array}$ \\
\hline $\begin{array}{l}\text { Grupe djece } \\
\text { predškolske dobi }\end{array}$ & $2,7 \%$ & $12,2 \%$ & $8,1 \%$ & $25,7 \%$ & $29,7 \%$ & $21,6 \%$ \\
\hline $\begin{array}{l}\text { Grupe djece (niži } \\
\text { razredi osnovne škole) }\end{array}$ & $1,4 \%$ & $1,4 \%$ & $2,7 \%$ & $12,2 \%$ & $25,7 \%$ & $56,8 \%$ \\
\hline $\begin{array}{l}\text { Grupe djece (viši razredi } \\
\text { osnovne škole) }\end{array}$ & $2,7 \%$ & $2,7 \%$ & $5,4 \%$ & $16,2 \%$ & $36,5 \%$ & $36,5 \%$ \\
\hline Grupe mladih (18 - 25) & $11,4 \%$ & $15,7 \%$ & $20,0 \%$ & $21,4 \%$ & $24,3 \%$ & $7,1 \%$ \\
\hline $\begin{array}{l}\text { Grupe odraslih dobi } \\
(25-65)\end{array}$ & $19,4 \%$ & $20,8 \%$ & $15,3 \%$ & $23,6 \%$ & $16,7 \%$ & $4,2 \%$ \\
\hline $\begin{array}{l}\text { Grupe djece (srednja } \\
\text { škola) }\end{array}$ & $4,1 \%$ & $11,0 \%$ & $8,2 \%$ & $27,4 \%$ & $30,1 \%$ & $19,2 \%$ \\
\hline Grupe odraslih iznad 65 & $27,8 \%$ & $22,2 \%$ & $19,4 \%$ & $23,6 \%$ & $4,2 \%$ & $2,8 \%$ \\
\hline $\begin{array}{l}\text { Grupe odraslih i djece/ } \\
\text { mladih (obitelji) }\end{array}$ & $20,5 \%$ & $23,3 \%$ & $23,3 \%$ & $23,3 \%$ & $8,2 \%$ & $1,4 \%$ \\
\hline $\begin{array}{l}\text { Grupe mladih i odraslih } \\
\text { osoba s invaliditetom } \\
(18+)\end{array}$ & $18,1 \%$ & $36,1 \%$ & $16,7 \%$ & $26,4 \%$ & $1,4 \%$ & $1,4 \%$ \\
\hline $\begin{array}{l}\text { Grupe djece s } \\
\text { invaliditetom }\end{array}$ & $27,8 \%$ & $25,0 \%$ & $16,7 \%$ & $23,6 \%$ & $4,2 \%$ & $2,8 \%$ \\
\hline $\begin{array}{l}\text { Grupe pripadnika } \\
\text { etničkih manjina }\end{array}$ & $48,6 \%$ & $22,9 \%$ & $11,4 \%$ & $11,4 \%$ & $1,4 \%$ & $4,3 \%$ \\
\hline
\end{tabular}


Slika 2. Za koje vrste posjetitelja i koliko često se organiziraju/provode aktivnosti u sklopu Akcije koje su namijenjene pojedinačnom sudjelovanju ili posjetu?

\begin{tabular}{|c|c|c|c|c|c|c|}
\hline & $\begin{array}{c}\text { Nikada } \\
0\end{array}$ & $\begin{array}{l}\text { Izuzetno } \\
\text { rijetko I }\end{array}$ & $\begin{array}{c}\text { Rijetko } \\
2\end{array}$ & $\begin{array}{c}\text { Povremeno } \\
3\end{array}$ & $\begin{array}{c}\text { Često } \\
4\end{array}$ & $\begin{array}{l}\text { Izuzetno } \\
\text { često } 5\end{array}$ \\
\hline Djeca predškolske dobi & $11,0 \%$ & $17,8 \%$ & $6,8 \%$ & $19,2 \%$ & $26,0 \%$ & $19,2 \%$ \\
\hline $\begin{array}{l}\text { Djeca u dobi koja } \\
\text { odgovara nižim } \\
\text { razredima osnovne } \\
\text { škole }\end{array}$ & $6,8 \%$ & $9,5 \%$ & $5,4 \%$ & $21,6 \%$ & $24,3 \%$ & $32,4 \%$ \\
\hline $\begin{array}{l}\text { Djeca u dobi koja } \\
\text { odgovara višim } \\
\text { razredima osnovne } \\
\text { škole }\end{array}$ & $8,1 \%$ & $9,5 \%$ & $6,8 \%$ & $28,4 \%$ & $23,0 \%$ & $24,3 \%$ \\
\hline $\begin{array}{l}\text { Djeca u dobi koja } \\
\text { odgovara srednjoj školi }\end{array}$ & $11,3 \%$ & $11,3 \%$ & $16,9 \%$ & $38,0 \%$ & $9,9 \%$ & $12,7 \%$ \\
\hline $\begin{array}{l}\text { Mladi između } 18 \text { i } 25 \\
\text { god. (studenti i osobe } \\
\text { sa završenom srednjom } \\
\text { školom) }\end{array}$ & $18,1 \%$ & $15,3 \%$ & $26,4 \%$ & $22,2 \%$ & $13,9 \%$ & $4,2 \%$ \\
\hline $\begin{array}{l}\text { Odrasli između } 25-65 \\
\text { god. }\end{array}$ & $21,4 \%$ & $18,6 \%$ & $18,6 \%$ & $28,6 \%$ & $8,6 \%$ & $4,3 \%$ \\
\hline Odrasli iznad 65 god. & $20,5 \%$ & $30,1 \%$ & $20,5 \%$ & $19,2 \%$ & $5,5 \%$ & $4,1 \%$ \\
\hline $\begin{array}{l}\text { Odrasli s djecom/ } \\
\text { mladima (obitelji) }\end{array}$ & $16,7 \%$ & $15,3 \%$ & $20,8 \%$ & $30,6 \%$ & $8,3 \%$ & $8,3 \%$ \\
\hline $\begin{array}{l}\text { Mlade i odrasle osobe s } \\
\text { invaliditetom }\end{array}$ & $28,6 \%$ & $31,4 \%$ & $15,7 \%$ & $18,6 \%$ & $2,9 \%$ & $2,9 \%$ \\
\hline Djeca s invaliditetom & $25,4 \%$ & $33,8 \%$ & $18,3 \%$ & $15,5 \%$ & $4,2 \%$ & $2,8 \%$ \\
\hline $\begin{array}{l}\text { Pripadnici etničkih } \\
\text { manjina }\end{array}$ & $47,1 \%$ & $25,7 \%$ & $12,9 \%$ & $12,9 \%$ & $\%$ & $1,4 \%$ \\
\hline
\end{tabular}

pitanje, odnosno ona koja se tiču ciljanih skupina, vrsta i svrhe aktivnosti, edukativnih ciljeva i usmjerenosti na njihovo postizanje.

Od 93 osobe koje su osobno sudjelovale u EMA-i, 16 je ravnatelja, 39 kustosa i 34 muzejska pedagoga (na svim razinama od vježbenika do savjetnika) te 6 osoba na drugim radnim mjestima (PR, stručni suradnici, dokumentarist). Oni dolaze iz različitih sredina i to prema sljedećim postotcima: mjesta manja od 10 tisuća stanovnika - 22,1\%, između 10 i 50 tisuća - 27,3 \% i više od 50 tisuća - 50,5\%. Po dužini aktivnoga sudjelovanja u provođenju akcija 27 muzealaca je sudjelovalo 1 - 5 godina, 20 muzealaca sudjelovalo je 6 - 10 godina, te 19 djelatnika 11 i više godina. Najveći točan broj bio je 23 godine (1 osoba).

Odgovori na prva dva pitanja odnose se na ciljane skupine, grupne i individualne posjete (Sl. 1, 2). 
Slika 3. Koje se vrste aktivnosti na temu Akcije i koliko često organiziraju/provode u Vašem muzeju?

\begin{tabular}{|c|c|c|c|c|c|c|}
\hline & Nikad & $\begin{array}{l}\text { Izuzetno } \\
\text { rijetko }\end{array}$ & Rijetko & Povremeno & Često & $\begin{array}{c}\text { Izuzetno } \\
\text { često }\end{array}$ \\
\hline & Row \% & Row \% & Row \% & Row \% & Row \% & Row $\%$ \\
\hline Radionice & $\%$ & $2,6 \%$ & $1,3 \%$ & $13,2 \%$ & $19,7 \%$ & $63,2 \%$ \\
\hline Predavanja & $8,3 \%$ & $13,9 \%$ & $8,3 \%$ & $33,3 \%$ & $25,0 \%$ & $11,1 \%$ \\
\hline Edukativne izložbe & $5,6 \%$ & $12,7 \%$ & $7,0 \%$ & $28,2 \%$ & $25,4 \%$ & $21,1 \%$ \\
\hline Igraonice & $14,9 \%$ & $12,2 \%$ & $8,1 \%$ & $18,9 \%$ & $23,0 \%$ & $23,0 \%$ \\
\hline Debate & $52,2 \%$ & $24,6 \%$ & $10,1 \%$ & $13,0 \%$ & $\%$ & $\%$ \\
\hline Okrugli stolovi & $52,2 \%$ & $24,6 \%$ & $11,6 \%$ & $10,1 \%$ & $\%$ & $1,4 \%$ \\
\hline $\begin{array}{l}\text { Tematska vodstva po } \\
\text { postavu }\end{array}$ & $2,8 \%$ & $5,6 \%$ & $4,2 \%$ & $5,6 \%$ & $35,2 \%$ & $46,5 \%$ \\
\hline Javne tribine & $62,3 \%$ & $23,2 \%$ & $7,2 \%$ & $4,3 \%$ & $2,9 \%$ & $\%$ \\
\hline Tečajevi & $63,2 \%$ & $19,1 \%$ & $10,3 \%$ & $7,4 \%$ & $\%$ & $\%$ \\
\hline
\end{tabular}

Odgovori pokazuju najveću učestalost provođenja programa za skupine djece nižih razreda osnovnih škola što je u skladu s grafičkom komunikacijom programske knjižice. Slijede viši razredi osnovne škole te predškolci i srednjoškolci. Pod ostale skupine posjetitelja ispitanici su naveli grupe stranih posjetitelja, stručne udruge, studente.

Kako u osnovnom komunikacijskom mediju (knjižici) akcije nisu popraćene tekstom koji upućuje komu je akcija namijenjena, ovi rezultati nam pokazuju kako se pojedinačni muzeji obraćaju širem krugu korisnika.

Na pitanje o vrstama aktivnosti i učestalosti njihova provođenja (Sl. 3) najčešći odgovori su radionice i tematska vodstva, no pojavljuju se u manjoj mjeri i drugi oblici aktivnosti.

Odgovori pokazuju da ne postoji niti jedan muzej koji nikada nije organizirao radionice povodom Akcije. Pod ostalim aktivnostima (koje nisu ponuđene) navedene su edukativne publikacije, predstave, koncerti, tematska vodstva na povremenoj izložbi i vezano za odabrano djelo, terenska istraživanja s korisnicima te posjeti umjetniku. Navedeno ukazuje na to da muzeji aktivnosti organiziraju prema vlastitim mogućnostima i zamislima. Pojedine vrste aktivnosti, kao na primjer organizirani tečajevi i javne tribine, dodatno sugeriraju proširenje korisničke baze s djece školske dobi na odrasle osobe. Velik broj radionica i vodstava po postavu također pokazuje da su aktivnosti koje se provode $\mathrm{u}$ sklopu akcije istovjetne aktivnostima koje se provode $\mathrm{u}$ redovitoj muzejsko-pedagoškoj praksi.

Odgovori na pitanje o evaluaciji programa i aktivnosti (Sl. 4) pokazuju da muzeji većinom ne provode evaluaciju. 
Slika 4. Je li se ikada u Vašem muzeju provela evaluacija programa/aktivnosti u sklopu Akcije ispitivanjem korisnika/ posjetitelja?

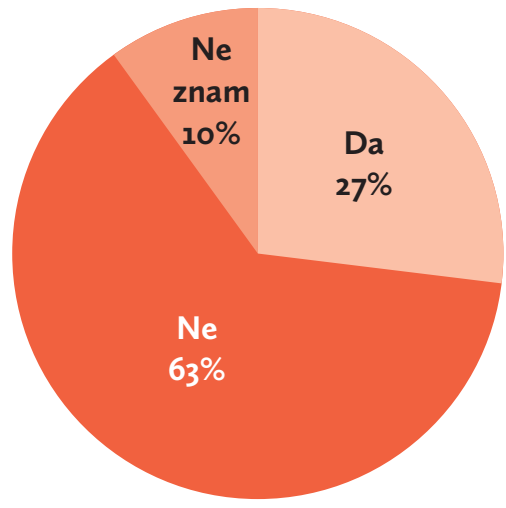

Slika 5. Određuje li se Vašem muzeju uspješnost aktivnosti u sklopu EMA-e?

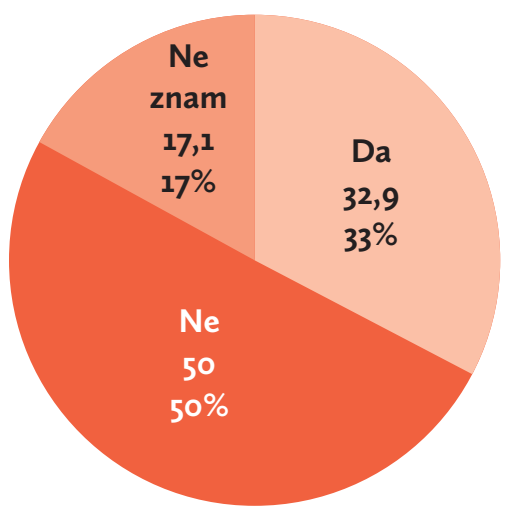

Ispitanici koji su provodili evaluaciju mogli su izabrati jedan ili više ponuđenih odgovora o tome što se točno vrednovalo: Zadovoljstvo korisnika (18), Doživljaj programa/ aktivnosti kod korisnika (17), Interes za sadržaj muzeja (12), Interes za temu programa/ aktivnosti (9), Stečeno znanje (7), Načine učenja (npr. kognitivni, društveni... vizualni, motorički...) (1). Odgovori pokazuju da se evaluacija temelji na ispitivanju doživljaja i zadovoljstva korisnika. Tek je 8 osoba odabralo opciju evaluacije koja se tiče stečenoga znanja ili načina učenja.

Na pitanje uspješnosti akcija, oko trećina ispitanika je odgovorila da se kod njih u muzejima određuje uspješnost, a u prazno polje namijenjeno popisu načina na koji se to čini navedeni su: broj posjetitelja i posjeta, anketiranje (evaluacija) te usmeni komentari sudionika, broj programa te popraćenost u medijima.

Na tri pitanja o percepciji nužnosti Akcije (Sl. 6), stavovi su podijeljeni. Interesi za akciju variraju, kao i njezin utjecaj na povećanje broja posjetitelja u muzeju općenito.

Odgovori na pitanje o doprinosu akcije za korisnike (Tab. 1) obrađeni su tematskom analizom kojom su dobivene dvije kategorije: perspektiva muzeja (lijevo) i perspektiva korisnika (desno). Perspektiva muzeja obuhvaća ishode koji zapravo doprinose muzejima, a perspektiva korisnika ishode koji doprinose korisnicima. Uz ishode je naveden broj odgovora.

Analiza pokazuje da se tek nekolicina ishoda može povezati s konkretnim edukacijskim ciljevima (razvijanje kritičkoga mišljenja, kreativnoga izražavanja, istraživanja, razvoj vlastitoga kulturnog identiteta). Iz navedenoga je evidentno da je većini muzeja (ili barem osobama koje su provodile aktivnosti) Akcija primarno sredstvo promoviranja institucije, muzejske djelatnosti te podizanja svijesti o muzejima. 
Slika 6. Koliko se slažete s ponuđenim tvrdnjama? (1 - nimalo, 5 - u potpunosti)

\begin{tabular}{|c|c|c|c|c|c|}
\hline & 1 & 2 & 3 & 4 & 5 \\
\hline $\begin{array}{l}\text { Sekcija za muzejsku pedagogiju dobro organizira } \\
\text { Edukativnu muzejsku akciju }\end{array}$ & $1,6 \%$ & $10,9 \%$ & $18,8 \%$ & $35,9 \%$ & $32,8 \%$ \\
\hline $\begin{array}{l}\text { Sekcija/Društvo dobro promoviraju Akciju u } \\
\text { medijima }\end{array}$ & $6,3 \%$ & $21,9 \%$ & $18,8 \%$ & $32,8 \%$ & $20,3 \%$ \\
\hline $\begin{array}{l}\text { Moj muzej se mora samostalno angažirati oko } \\
\text { promocije }\end{array}$ & $\%$ & $1,6 \%$ & $25,0 \%$ & $20,3 \%$ & $53,1 \%$ \\
\hline $\begin{array}{l}\text { Dobro je da muzeji financijski participiraju u Akciji } \\
\text { (kotizacijom, kupovinom dodatnih knjižica) }\end{array}$ & $14,1 \%$ & $18,8 \%$ & $31,3 \%$ & $17,2 \%$ & $18,8 \%$ \\
\hline $\begin{array}{l}\text { Muzej mi omogućava potrebne uvjete za } \\
\text { provedbu Akcije }\end{array}$ & $4,7 \%$ & $12,5 \%$ & $12,5 \%$ & $21,9 \%$ & $48,4 \%$ \\
\hline $\begin{array}{l}\text { Kolege u muzeju pomažu pri organizaciji } \\
\text { programa u sklopu Akcije }\end{array}$ & $12,5 \%$ & $12,5 \%$ & $21,9 \%$ & $15,6 \%$ & $37,5 \%$ \\
\hline $\begin{array}{l}\text { Kolege u muzeju pomažu pri provedbi programa u } \\
\text { sklopu Akcije }\end{array}$ & $12,5 \%$ & $14,1 \%$ & $25,0 \%$ & $15,6 \%$ & $32,8 \%$ \\
\hline $\begin{array}{l}\text { Interes ciljane skupine korisnika za programe u } \\
\text { sklopu Akcije je velik }\end{array}$ & $7,8 \%$ & $15,6 \%$ & $35,9 \%$ & $26,6 \%$ & $14,1 \%$ \\
\hline $\begin{array}{l}\text { Akcija je nužna jer pozitivno utječe na povečani } \\
\text { broj posjetitelja tijekom cijele godine }\end{array}$ & $4,7 \%$ & $25,0 \%$ & $26,6 \%$ & $14,1 \%$ & $29,7 \%$ \\
\hline $\begin{array}{l}\text { Akcija je nužna jer muzeji inače ne nude dovoljno } \\
\text { sadržaja za djecu }\end{array}$ & $18,8 \%$ & $28,1 \%$ & $17,2 \%$ & $21,9 \%$ & $14,1 \%$ \\
\hline $\begin{array}{l}\text { Aktivnosti planirane u sklopu Akcije u mojem } \\
\text { muzeju se spremno financiraju (makar s malim } \\
\text { iznosima) }\end{array}$ & $6,3 \%$ & $9,4 \%$ & $14,1 \%$ & $25,0 \%$ & $45,3 \%$ \\
\hline
\end{tabular}

Tablica 1. Koji je doprinos muzejskih aktivnosti u sklopu EMA-e za posjetitelje, odnosno korisnike muzeja?

\begin{tabular}{|l|l|}
\hline PERSPEKTIVA MUZEJA & PERSPEKTIVA KORISNIKA \\
\hline Promocija muzeja i muzejskih zbirki (10) & $\begin{array}{l}\text { Učenje i informiranje o određenoj temi ili sadržaju } \\
(9)\end{array}$ \\
\hline $\begin{array}{l}\text { Veći broj posjeta i posjetitelja (7), Stvaranje nove } \\
\text { muzejske publike (2), Odgajanje publike (3) }\end{array}$ & $\begin{array}{l}\text { Kvalitetno provođenje slobodnog vremena - } \\
\text { edukacija kroz zabavu (4) }\end{array}$ \\
\hline Obogaćeni sadržaj (7) & Poticanje znatiželje i interesa (1) \\
\hline Upoznavanje s djelatnošću i značenjem muzeja (7) & Razvoj znanja, interesa, vještina (2) \\
\hline Promocija publikacija (1) & Razvijanje kritičkog mišljenja (1) \\
\hline Promocija baštine (2) i edukativne djelatnosti (1) & Razvijanje kreativnog izražavanja i istraživanja (2) \\
\hline Senzibilizacija (ne)posjetitelja za muzeje (3) & Razvoj vlastitog kulturnog identiteta (1) \\
\hline
\end{tabular}


Slika 7. Koliko se slažete sa sljedećim tvrdnjama? (1- nimalo se ne slažem, 5 - u potpunosti se slažem)

\begin{tabular}{|l|c|c|c|c|c|c|}
\hline & $\mathbf{1}$ & $\mathbf{2}$ & $\mathbf{3}$ & $\mathbf{4}$ & $\mathbf{5}$ & Average \\
\hline $\begin{array}{l}\text { Provodenje Akcije/a dovelo je do } \\
\text { pozitivnih promjena u mojoj instituciji }\end{array}$ & $9,4 \%$ & $14,1 \%$ & $25,0 \%$ & $18,8 \%$ & $32,8 \%$ & 3,5 \\
\hline $\begin{array}{l}\text { Provodenje Akcija dovelo je do } \\
\text { pozitivnih promjena u muzejima uopće }\end{array}$ & $0,0 \%$ & $14,1 \%$ & $28,1 \%$ & $31,3 \%$ & $26,6 \%$ & 3,7 \\
$\begin{array}{l}\text { Provodenje Akcija dovelo je do } \\
\text { pozitivnih promjena u društvu (kod } \\
\text { muzejskih korisnika) }\end{array}$ & $6,3 \%$ & $21,9 \%$ & $29,7 \%$ & $23,4 \%$ & $18,8 \%$ & 3,3 \\
\hline
\end{tabular}

Na pitanje o promjenama koje je donijela Akcija (Sl. 7) mišljenja su ujednačena. Ispitanici se najmanje slažu s tvrdnjom da je provođenje Akcije dovelo do pozitivnih promjena u društvu (kod muzejskih korisnika). Analiza komentara uz ovo pitanje pokazuje sljedeće stavove koji su vezani za pozitivne promjene u specifičnom muzeju i muzejima općenito: veći opseg edukativnih muzejskih materijala i edukativnih aktivnosti, veća vidljivost i pozitivniji stav prema muzeju, proširenje baze korisnika (mlađi i odrasli s djecom).

U zadnjem pitanju u anketi, kojem je cilj bio pokazati mišljenje o (mogućem) daljnjem razvoju Akcije, ispitanike se pitalo kako bi se Akcija trebala provoditi u budućnosti (Sl. 8). Ponuđeni odgovori su bili: ukinuti, provoditi u drukčijem obliku, provoditi u istom obliku kao do sada i drugo. Odgovori su podijeljeni i vrlo je mali postotak onih koji je više ne žele. Veoma mala prednost je dana mišljenjima da se Akcija treba provoditi u drugačijem obliku.

Kategorija "drugo" u kojoj se ipak predlažu neke promjene uključivala je sljedeća konkretne prijedloge: 1 . provoditi $\mathrm{u}$ istom obliku i nadopuniti digitalnom aplikacijom; 2 . ne mijenjati sadržaj, nego inzistirati na medijskoj promociji kako bi akcija privukla što više korisnika; 3. prilagoditi potrebama društva na osnovi povratnih informacija sudionika.

Slika 8. Mišljenja o provođenju Akcije u budućnosti

Provoditi u istom obliku kao do sada

Provoditi u drukčijem obliku

Ukinuti

Drugo (upisati)

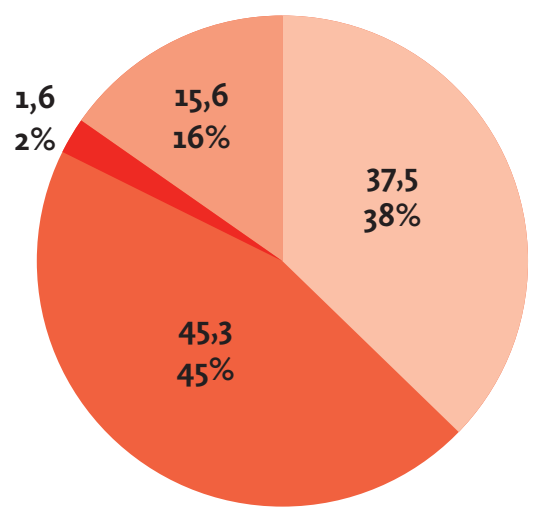


Komentari dani na kraju ankete u polju koje nije vezano niti za jedno pitanje nego je dano mjesto za one koji bi htjeli nešto nadodati, uglavnom se ili kreću u smjeru traženja novoga koncepta ili su pozitivne ocjene Akcije. Njima se potvrđuju podijeljena mišljenja o mogućem budućem obliku Akcije. Ovdje donosimo one koje smatramo važnim za raspravu:

"Akciju treba potpuno redefinirati, dosadašnja praksa pokazuje da postojeće aktivnosti malo modificiramo da se uklope $u$ akciju, međutim vidljivost naših sadržaja s time se ne povećava:, za korisnike se borimo isključivo sami; knjižica baš i nema neku funkciju osobito stoga jer je dobijemo 5 kom - taman za arhivu, i nisam sigurna da su informacije u njoj potrebne korisnicima."

“Nažalost Akcija postaje 'mrtvi konj' kojeg se i dalje gura, a ne bitna stvar koja je nužna i potrebna za muzejske ustanove."

"Akciju korisnici pozitivno ocjenjuju. Oni koji se uključe programe prate sa zanimanjem i veseljem, ali javnost je općenito nedovoljno informirana o akciji pa je i odaziv relativno skroman."

"Pohvaljujem akciju, zahvaljujući njoj pokrenut je u našem muzeju od 2013. velik broj muzejskih radionica i dodatnih programa (i van Dana muzeja), što je konačno rezultiralo i zaposlenjem muzejskog pedagoga i osmišljavanjem cjelogodišnjeg sustava radionica i edukacija."

\section{RASPRAVA}

Analiza programske knjižice Edukativne muzejske akcije (EMA) otvorila je nekoliko ključnih pitanja. Među njima se posebno izdvaja pitanje ciljane skupine korisnika - grupni ili individualni posjeti, dobna skupina korisnika. Ono je važno i iz perspektive razloga pokretanja Akcije, ali i prakse koja bi se trebala provoditi u budućnosti. Naime, kako je na više mjesta istaknuto, prva Akcija, odnosno edukativna igra 1996. godine, bila je namijenjena isključivo djeci osnovnoškolske dobi koja su samostalno, kao individualni posjetitelji (u pratnji odrasle osobe) obilazila muzeje. Anketa je pokazala kako se nakon više od 20 godina, raspon profila sudionika za koje se organiziraju aktivnosti tijekom Akcije znatno proširio. Samo po sebi to nije problematično, no ako se, pak, sagleda iz kuta organizirane akcije koja bi trebala imati jasno definiranu ciljanu skupinu i jasno definiran cilj (u ovom slučaju na razini cijele države), šaroliki podaci dobiveni anketom i analizom knjižice potiču na propitivanje smisla akcije kao jedinstvenoga djelovanja. Moguće je, također, postaviti i pitanje održivosti i smislenosti Akcije koja nema definirani niti opći niti specifične ciljeve pa je onda, naravno, nemoguće pratiti jesu li oni i u kojoj mjeri ostvareni. Drugim riječima manje ukazuju na obilježja edukativne, a više na karakteristike informativne akcije (Hammersley 2003.).

Odgovori o korisnosti Akcije najilustrativnije pokazuju da muzealci, i to oni koji organiziraju i/ili provode edukativne aktivnosti, Akciju promatraju više kao promotivni program koji primarno animira i senzibilizira, nego li se bavi postizanjem konkretnih obrazovnih ciljeva. Sličan stav o potrebi senzibilizacije i animacije posjetitelja isticao 
se u hrvatskom kontekstu 1970-ih i 1980-ih godina (Bauer 1975., Majanović 1994.) kada je to bilo i nužno. Dvadeset prvo stoljeće, sa znatno razvijenijim marketinškim razmišljanjima i djelovanjima, ostavlja dovoljno prostora edukacijskoj djelatnosti da se usmjeri na postizanje "viših", pa i društveno relevantnih, ciljeva u smislu ukazivanja na aktualne društvene probleme i doprinos njihovu rješavanju, što je u suvremeno doba prepoznato kao jedna od primarnih uloga muzeja (Brown i Mairesse 2018., Fleming 2016.). Daljnja istraživanja muzejske edukativne akcije bi stoga mogla biti usmjerena i na istraživanje s aspekta društveno-angažiranoga djelovanja muzeja, odnosno mogla bi uključiti i aspekte društvene akcije (Hein 2010.). U tom se smislu, ovim istraživanjem ponudio tek jedan pristup određenju edukativne akcije. Istraživanje je pokazalo da edukativna muzejska akcija, kakva se trenutno provodi u Hrvatskoj, osim raznolikosti vrsta aktivnosti, nema dostatnih elemenata temeljem kojih bi se mogla okarakterizirati kao posebno organizirani pothvat s ciljem edukacije definirane skupine korisnika i sa svrhom postizanja specifično definiranih učinaka. Provedba Akcije se u programskim publikacijama ne specificira na razini zajedničkoga djelovanja. Ona je tek poziv na što veće uključivanje koje je samo sebi svrhom. Pritom se, vrlo legitimno, shvaća da je svaka vrsta edukacije poželjna i vrijedna. Provođenje edukacije koja nema definiran specifičan cilj, trebalo bi biti dio redovite prakse muzeja, a ne rezultat odaziva na Akciju, odnosno Akcija ne bi trebala biti izlikom za provođenje poneke edukativne aktivnost jednom godišnje. Nažalost, ili na sreću, navedeno je često posljedica nedostatka financijskih uvjeta, ali u pojedinim slučajevima, i još uvijek nedostatne svijesti uprave i osnivača o potrebi provođenja edukativnih aktivnosti i (često) nedostatka radnoga mjesta muzejskog pedagoga. Kod nešto većih muzeja kojima je edukativna djelatnost dio redovite prakse, provedba akcije se često ostavlja na volju pojedincu (muzejskom pedagogu/-inji), i o njemu/njoj ovisi hoće li je shvatiti kao nadogradnju u smislu specifičnoga oblika djelovanja ili će joj prilagoditi programe/aktivnosti koje ionako provodi u redovitoj praksi. Odgovori na pitanje o daljnjem razvoju Akcije i pojedini komentari ukazuju na činjenicu da kod pojedinaca postoji vrlo razvijena svijest o potrebi promjene Akcije u vidu njezine nadogradnje. No, potrebu za promjenama/nadogradnjom, kad već govorimo o akcijama kao posebnim pothvatima, trebaju osvijestiti i krovni organizatori, te dati poticaj i smjernice drugima.

\section{ZAKLJUČAK}

Više od dva desetljeća organiziranoga djelovanja prvo isključivo zagrebačkih, a onda i većine hrvatskih muzeja, u sklopu muzejske edukativne igre/akcije, zaslužuje svake pohvale. Nedvojbeno je da se radi o vrijednoj (i u globalnom kontekstu jedinstvenoj) muzejskoj tradiciji, začetoj u specifičnim (nepovoljnim) poslijeratnim okolnostima. Također je nedvojbeno da je Akcija doprinijela afirmaciji muzejsko-pedagoške struke. Stoga ne čudi interes muzealaca (primarno muzejskih pedagoga/-inja) za održavanjem ovakva djelovanja. Međutim, kako je s godinama struka ipak ojačala, očekivano bi bilo pomicanje granica djelovanja, odnosno promišljanje i definiranje novih ciljeva koji bi proizlazili iz suvremenih okolnosti i odgovarali na suvremene izazove. Osim proširenja ciljane skupine, koje nisu pratile sadržajne promjene u smislu prilagodbe koncepta, aktivnosti pa ni dizajna promidžbenoga materijala, provedeno istraživanje je pokazalo 
kako pomaka zapravo nema. Štoviše, rezultati pokazuju da se organizirana edukativna akcija primarno shvaća kao djelovanje u svrhu popularizacije muzeja i muzejskih sadržaja te komunikacije informacija. Edukativna muzejska akcija (EMA) ne posjeduje svojstvo edukativne akcije u smislu zadovoljavanja prije navedenih ključnih kriterija obraćanje jasno definiranoj ciljanoj skupini, jasno definirane aktivnosti i svrha te jasno definirani edukacijski ciljevi i usmjerenost na njihovo provođenje. Štoviše, analiza je pokazala da igra provedena 1996. godine više zadovoljavala navedene kriterije nego li Edukativna muzejska akcija, osobito od 2006. godine na dalje. Stanje stvari može se djelomice protumačiti još uvijek nedovoljnim brojem muzejskih pedagoga zaposlenih u muzejima, odnosno nedovoljnim kapacitetima nužnim za uvođenje (i provedbu) promjena, ali odgovori u provedenoj anketi (posebice mali broj komentara na kraju ankete) upućuje i na nedostatak interesa za promišljanjem svrhe i ciljeva Akcije. Kao najdugovječnije organizirano muzejsko-pedagoško djelovanje u Hrvatskoj, Edukativna muzejska akcija svakako ima potencijala da se razvije u edukativnu akciju u punom smislu, no čini se da je preduvjet tomu temeljito preispitivanje muzejsko-pedagoške struke u Hrvatskoj, koja je ukidanjem zvanja muzejskoga pedagoga Pravilnikom o stručnim muzejskim zvanjima i drugim zvanjima u muzejskoj djelatnosti te uvjetima i načinu njihova stjecanja donesenoga 2019. dodatno poljuljana.

\section{LITERATURA I IZVORI:}

AKCIJA, Hrvatski jezični portal, http://hjp.znanje.hr/index.php?show=search (pristup 25.2.2020.).

ACTION, Cambridge Dictionary, 2018. https://dictionary.cambridge.org/dictionary/english/ action (pristup 25.2.2020.).

AIDAR, Gabriela i Luciana CONRADO MARTINS. 2018. "Cultural action in museums: What do professionals and researchers think in the Latin American context?" U: ICOM Education 28 - Cultural Action, Stéphanie Wintzerith, ur. Paris: ICOM CECA, str. 159-173.

BAUER, Antun. 1975. "Muzejska pedagogija”. Muzeologija 17: 101-111. https://doi. org $/ 10.1137 / 1017006$

BREZINŠČAK, Renata. 2019. Bibliografija radova objavljenih u zbornicima skupova muzejskih pedagoga hrvatske od br. I. do VIIIs. (2002. - 2015.). Zagreb: Hrvatsko muzejsko društvo, http://www.hrmud.hr/sekcija_pedagoga/Zbornici_Skupova_muzejskih_pedagoga_Hrvatske_bibliografija.pdf (pristup 30.3.2020.).

BREZINŠČAK, Renata i Željka JELAVIĆ. 1996. "Uloga i status kustosa pedagoga u djelatnosti muzeja”. Anali Galerije Antuna Augustinčića, 16/17: 101-106. http://muzejska-edukacija. com/uloga-i-status-kustosa-pedagoga-u-djelatnosti-muzeja/ (pristup 12.4.2012.).

BROWN, Kareb i Francois MAIRESSE. 2018. "The definition of museum through its social role". Curator 61 (4): 1-15. https://doi.org/10.1111/cura.12276

CUKROV, Tončika. 2006. "Međunarodni dan muzeja 2006. “ Informatica Museologica 37 (1-4): 188-201.

ÉMOND, Anne-Marie i João Pedro PAIS MENDONÇA. 2018. "Cultural action-making in English Canada's museums: a historical overview 1840-2018”. U: ICOM Education 28 Cultural Action, Stéphanie Wintzerith, ur. Paris: ICOM CECA, str. 89-108. 
FLEMING, David. 2016. "Post-social Role of Museums", July 19, 2016. Musing on Culture, http://musingonculture-en.blogspot.com/2016/07/guest-post-social-role of- museumsnew.html (pristup 13.12.2019.).

HAMMERSLEY, Martyn. 2003. "Can and Should Educational Research be Educative?". Oxford Review of Education 29(1): 3-25. https://doi.org/10.1080/03054980307433

HEIN, George E. 2010. "The Role Of Museums In Society: Education And Social Action". Curator 48(4): 357-363. https://doi.org/10.1111/j.2151-6952.2005.tb00180.x

ICOM, Development of the Museum Definition according to ICOM Statutes (2007 - 1946), http://archives.icom.museum/hist_def_eng.html (pristup 2.10.2019.).

JELAVIĆ, Željka. 2011. “O statusu i profesionalizaciji muzejske edukacije u Hrvatskoj”. U: Zbornik radova 1. kongresa muzealaca Hrvatske, Žarka Vujić, ur. Zagreb: Hrvatsko muzejsko društvo, str. 58-62. http://muzejska-edukacija.com/o-statusu-i-profesionalizacijimuzejske-edukacije-i-u-hrvatskoj/ (pristup 10.3.2012.).

LASZLO, Želimir. 1997. “Što je u muzeju oduševilo Baltazara?”. Informatica Museologica 1/4: 22-26.

LEINER, Vesna i Renata BREZINŠČAK. 2016. "Djelovanje Sekcije za muzejsku pedagogiju i kulturnu akciju HMD-a”. Vijesti muzealaca i konzervatora, str. 38-47.

MAJANOVIĆ, Nada. 1994. "Dr. Bauer i... muzejska pedagogija”. Muzeologija 31: 29-33.

MUZEJSKI DOKUMENTACIJSKI CENTAR, Hrvatski muzeji i zbirke online, https://hvm. mdc.hr/ (pristup 10.6.2018.).

Pravilnik o stručnim muzejskim zvanjima i drugim zvanjima u muzejskoj djelatnosti te uvjetima i načinu njihova stjecanja. (NN 104/2019) (pristup 30.10.2019.)

https://narodne-novine.nn.hr/clanci/sluzbeni/full/2019_10_104_2089.html (pristup 23.3.2020.)

SMETKO, Andreja. 2006. "11. Muzejska edukativna i nagradna igra Zvuk... Ton...Glas". Informatica Museologica 37 (1-4): 218-219.

ŠKARIĆ, Mila. 2002. “Muzejska pedagogija u Hrvatskoj”. U: II. Skup muzejskih pedagoga Hrvatske s međunarodnim sudjelovanjem, Mila Škarić, ur. Zagreb: Hrvatsko muzejsko društvo, str. 7-13.

ŠKARIĆ, Mila. 2007. "Solisti ili članovi orkestra”. U: IV. Skup muzejskih pedagoga Hrvatske s međunarodnim sudjelovanjem, Božidar Pejković, ur. Zagreb: Hrvatsko muzejsko društvo, str. 27-36.

ŠKARIĆ, Mila. 2010. “Kriza i analiza statusa muzejskih pedagoga hrvatske 2010.”. U: VI. skup muzejskih pedagoga Hrvatske s međunarodnim sudjelovanjem. Željka Jelavić i Renata Brezinščak, ur. Zagreb: Hrvatsko muzejsko društvo, str. 19-35.

WINTZERITH, Stéphanie (ur.) 2018a. ICOM Education 28 - Cultural Action. Paris: ICOM CECA.

WINTZERITH, Stéphanie 2018b. "As way of introduction". U: ICOM Education 28 - Cultural Action, Stéphanie Wintzerith, ur. Paris: ICOM CECA, Paris: ICOM CECA, str. 7-21.

Zakon o muzejima, (NN 61/2018), (NN 98/2019.). https://www.zakon.hr/z/302/Zakon-omuzejima (pristup 17.4.2020.). 